\title{
Isochavicinic Acid and Steroids from Gomphrena globosa L.
}

\author{
Md. Hamiduzzaman, Choudhury M. Hasan, A.T.M. Zafrul Azam \\ Phytochemical Research Laboratory, Department of Pharmaceutical Chemistry, Faculty of Pharmacy, \\ University of Dhaka, Dhaka-1000, Bangladesh
}

From the crude methanol extract of whole plant of Gomphrena globosa (L.), three compounds stigmasterol (1), $\beta$-sitosterol (2) and isochavicinic acid (3) were isolated by a combination of column chromatography and preparative thin layer chromatography over silica gel. The structures of these compounds were determined by ${ }^{1} \mathrm{H}$ NMR spectroscopic method and comparing with published data.

Bangladesh is a good repository of medicinal plants comprising of various families including Amaranthaceae. ${ }^{1}$ The plants of Amaranthaceae family contain a wide range of pharmacologically active compounds and possess various types of traditional uses like oliguria, heat and empacho, hypertension, ${ }^{2}$ and diabetes. ${ }^{3}$ G. globosa (L.), (Bengali name - Botam phul) is distributed in all over Bangladesh and commonly known as Globe Amaranth. It is cultivated as an ornamental flowering annual herb in garden that bears globe like flowers. Throughout the world there are 176 genera and 2400 species and among them around 30 members are common in Bangladesh..$^{4-5}$ Studies of a large number of amaranthous plants have shown to contain a wide range of secondary metabolites such as (E)-3-O-Dglucopyranosyl-4,5,6,4-tetrahydroxy-7-dimethoxyaurone, ${ }^{6}$ aurantiamide acetate, tiliroside, ${ }^{7}$ 3-(4hydroxyphenyl) methylpropeonate, ${ }^{8}$ methylenedioxyflavonol-gomphrenol, gomphrenol, ${ }^{9} \beta$-cyanins, gomphrenin $\mathrm{I}-\mathrm{III},{ }^{10}$ flavones and flavonoids glycoside. ${ }^{11}$ Since this plant has good medicinal

Correspondence to: A.T.M. Zafrul Azam, Tel. +880-1710-880064; Fax: +880-2-8615583; Email address: zafrulazam@du.ac.bd

Dhaka Univ. J. Pharm. Sci. 11(1): 79-81, 2012 (June) properties, the present work has been undertaken to isolate and identify biologically active secondary metabolites and we, here in, report the structural elucidation of three compounds, stigmasterol (1), $\beta$-sitosterol (2) and isochavicinic acid (3) by using ${ }^{1} \mathrm{H}$ NMR spectroscopic method.

The ${ }^{1} \mathrm{H}$ NMR spectra were recorded using a Bruker AMX-500 (500 MHz) instrument and the spectra were referenced to the residual nondeuterated solvent signal. PTLC and TLC were carried out using Merck Si gel $\mathrm{F}_{254}$ on glass plates at a thickness of 0.5 $\mathrm{mm}$. Spots on TLC and PTLC plates were visualized by spraying the developed plates with vanillinsulfuric acid followed by heating for 5 minutes at 110 ${ }^{\circ} \mathrm{C}$. All solvents used in this study were of reagent grade.

Whole plant of G. globosa was collected from Dhaka in November 2011. A voucher specimen (Accession no. 3557) for this collection has been deposited in University of Dhaka, herbarium for future reference.

The powdered whole plant ( $800 \mathrm{~g}$ ) of G. globosa was extracted at room temperature with $3.5 \mathrm{~L}$ of methanol for 15 days and filtered through a cotton plug followed by Whatman filter paper no 1 . The extract was then concentrated with a rotary evaporator. The crude methanol extract (20 gm) was fractionated by vacuum liquid chromatographic (VLC) technique over silica gel $60 \mathrm{H}$ by using $n$-hexane and ethyl acetate in different proportions. This provided 20 VLC fractions. Following TLC of VLC fractions-07, 08 and 11, they were subjected to column chromatography for further fractionation by using lipophilic Sephadex (LH-20) and chloroform- 
pet. ether combination as mobile phase. This yielded three compounds, stigmasterol (1) $\left(\mathrm{R}_{\mathrm{f}}=0.33\right.$ in toluene-ethyl acetate, 95:5), $\beta$-sitosterol (2) $\left(\mathrm{R}_{\mathrm{f}}=\right.$ 0.501 in toluene-ethyl acetate, 95:5) and isochavicinic acid (3) $\left(\mathrm{R}_{\mathrm{f}}=0.44\right.$ in toluene-ethyl acetate, 80:20).

Stigmasterol (1) was characterized according to the published data and it was found as needle shaped off white powder. ${ }^{12}{ }^{1} \mathrm{H}$ NMR (500 MHz, $\mathrm{CDCl}_{3}$ ): $\delta$ $3.5(1 \mathrm{H}, \mathrm{m}, \mathrm{H}-3), 5.34$ (1H, br. s, H-6), 0.67 (Me13), $1.00(\mathrm{Me}-10), 0.81(J=7.4 \mathrm{~Hz}, \mathrm{Me}-20), 5.16$ $(1 \mathrm{H}, d d, J=15.0,6.5 \mathrm{~Hz}, \mathrm{H}-22), 5.03(1 \mathrm{H}, d d, J=$ 15.0, $9.0 \mathrm{~Hz}, \mathrm{H}-23), 0.83$ (H-26), 0.84 (H-27), 0.92 (d, $J=6.4 \mathrm{~Hz}, \mathrm{Me}-28)$.

$\beta$-sitosterol (2) was characterized according to the published data of Morales et al. ${ }^{13}$ which was found as colorless crystalline mass. ${ }^{1} \mathrm{H}$ NMR (500 $\left.\mathrm{MHz}, \mathrm{CDCl}_{3}\right): \delta 3.51,(1 \mathrm{H}, \mathrm{m}, \mathrm{H}-3), 5.34,(1 \mathrm{H}, d$, $J=5.2 \mathrm{~Hz}, \mathrm{H}-6), 0.67$ (Me-13), 1.00 (Me-10), 0.85, $(1 \mathrm{H}, d, J=7.0 \mathrm{~Hz}, \mathrm{H}-29), 0.83,(1 \mathrm{H}, d, J=7.0 \mathrm{~Hz}, \mathrm{H}-$ 26), 0.81, (1H, $d, J=7.0 \mathrm{~Hz}, \mathrm{H}-27), 0.92,(1 \mathrm{H}, d, J=$ $6.4 \mathrm{~Hz}, \mathrm{H}-21)$

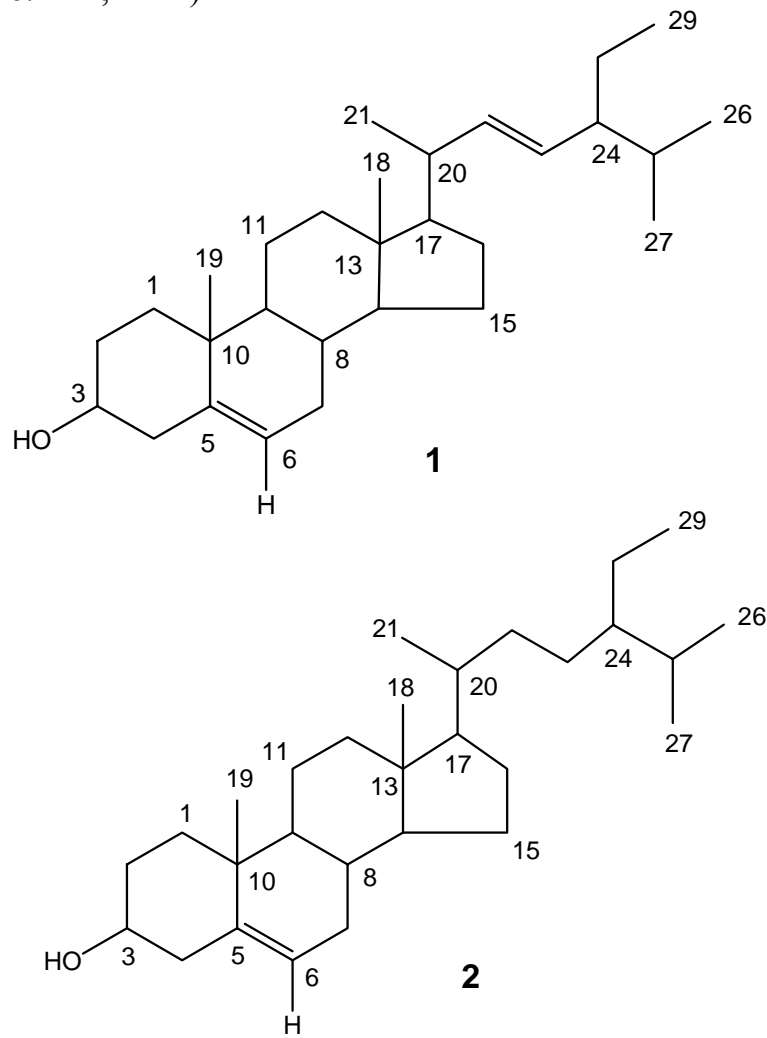

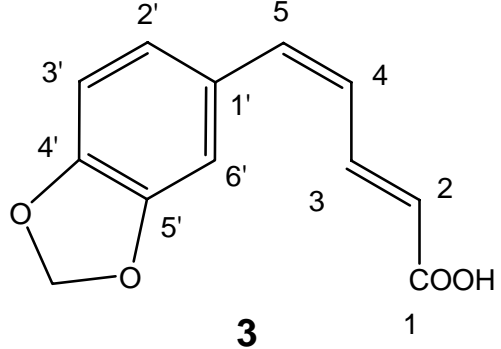

Isochavicinic acid (3) was found as yellowish precipitate; ${ }^{1} \mathrm{H}$ NMR $\left(500 \mathrm{MHz}, \mathrm{CDCl}_{3}\right): \delta 6.43(1 \mathrm{H}$, $d, J=15.0 \mathrm{~Hz}, \mathrm{H}-2), 7.40(1 \mathrm{H}, d d d, J=15.0,8.5,1.5$ $\mathrm{Hz}, \mathrm{H}-3), 5.94\left(2 \mathrm{H}, \mathrm{s}, \mathrm{CH}_{2} \mathrm{O}\right) \mathrm{s}, 6.75$ (br. s, H-5), $6.90(1 \mathrm{H}, d d, J=8.0,1.5 \mathrm{~Hz}, \mathrm{H}-2 '), 6.78(1 \mathrm{H}, d, J=$ $\left.8.0 \mathrm{~Hz}, \mathrm{H}-3^{\prime}\right), 6.98(1 \mathrm{H}, d, J=1.5 \mathrm{~Hz}, \mathrm{H}-6$ '), 6.70 $(1 \mathrm{H}, d, J=9.0 \mathrm{~Hz}, \mathrm{H}-4)$.

The ${ }^{1} \mathrm{H}$ NMR spectral data indicated the presence of a 1,3,4-trisubstituted aromatic ring with resonances at $\delta 6.78(1 \mathrm{H}, d, J=8.0 \mathrm{~Hz}), 6.90(1 \mathrm{H}$, $d d, J=8.0,1.5 \mathrm{~Hz})$ and $6.98(1 \mathrm{H}, \mathrm{d}, J=1.5 \mathrm{~Hz})$. The spectrum also showed a singlet of two proton intensity at $\delta 5.94$ typical for methylenedioxy functionality. In addition, the ${ }^{1} \mathrm{H}$ NMR spectrum demonstrated four olefinic proton signals at $\delta 6.43$ $(1 \mathrm{H}, d, J=15.0 \mathrm{~Hz}), 6.70(1 \mathrm{H}$, br. s), $6.75(1 \mathrm{H}$, br. s), and $7.40(1 \mathrm{H}, d d d, J=15.0,8.4,1.5 \mathrm{~Hz})$. The large coupling $(J=15.0 \mathrm{~Hz})$ between the protons resonating at $\delta 6.43$ and 7.40 suggested trans orientation, while the downfield shift of the latter proton allowed to place it at beta $(\beta)$ position to a carboxylic acid group. On this basis, compound $\mathbf{3}$ was characterized as isochavicinic acid. The identity of $\mathbf{3}$ was further confirmed by comparing its spectral data with previously reported values as well as by co-TLC with an authentic sample of isochavicinic acid previously isolated in our laboratory. ${ }^{14}$ This is the first report of isochavicinic acid from this plant.

\section{ACKNOWLEDGEMENT}

The authors would like to thank Mr. Fakir Tareq for his support in recording NMR spectra of the samples in South Korea. 


\section{REFERENCES}

1. Muller, K. and Borsch, T. 2005. Phylogenetics of amaranthaceae using matK/trnK sequence data - evidence from parsimony, likelihood and Bayesian approaches. An. Missouri Bot. Garden. 92, 66-102.

2. Yusuf, A.A., Iwuafor, E.N.O., Abaidoo, R.C., Olufajo, O.O. and Sanginga, N. 2009. Grain legume rotation benefits to maize in the northern Guinea savanna of Nigeria: Fixednitrogen vs. other rotation effects. Nutr. Cycl. Agroecosyst. 84, 129-139.

3. Arcanjo, D.D.R., de Albuquerque, A.C.M., Neto, B.N., Silva, N.C.B.S, and Moita, M.M. 2011. Phytochemical screening and evaluation of cytotoxic, antimicrobial and cardiovascular effects of Gomphrena globosa L ethanolic extraction. J. Med. Plants Res. 5, 2006-2010.

4. Judd, W.S., Campbell, C.S., Kellogg, E.A., Stevens, P.F. and Michael J. Donoghue, M.J. 2007. Plant Systematics: A Phylogenetic Approach, 3rd edition, Sinauer Associates, Inc.

5. Kadereit, G., Hohmann, S. and Kadereit, J.W. 2006. A synopsis of Chenopodiaceae sub fam. Betoideae and notes on the taxonomy of Beta. Willdenowia. An. Bot. Garden Bot. Museum Berlin-Dahlem, 36, 9-19.

6. Savchenko, T., Whiting, P., Sarker, S. D. and Dinan, L. 1998. Ecdysteroids from Gomphrenahaageana (Amaranthaceae). Biochem. Syst. Ecol. 24, 177- 178.
7. Buschi C. A. and Pomilio A. B. 1982.Terpenoids, flavonoids and protoalkaloids from Gomphrenaboliviana. An. Assoc. Quimica Argentina 70, 855-861.

8. Grove, D.C. and Randall, W.A. 1955. Assay Methods of Antibiotics: a Laboratory Manual (Antibiotics monographs, 02). Medical Encyclopedia Inc, New York.

9. Aziz, N. H., Farag, S.E., Mousa, L.A.A. and Abo-Zaid, M.A. 1998. Comparative antibacterial and antifungal effects of some phenolic compounds. Microbios, 93, 43-54.

10. Ghani, A. 2000. Vheshaja Oshudh (Herbal Medicine), Bangla Academy Dhaka, Bangladesh.

11. Rastogi, R.P. and Mehrotra, B.N. 2003. Compendium of Indian Medicinal Plants. vol 2. Publications and Information Directorate, New Delhi, India, p. 179

12. Khan, R.I. 1991.Natural Product: A Laboratory Guide, $2^{\text {nd }}$ Ed.; Academic Press, N.Y., USA.

13. Morales, G., Sierra, P., Mancilla, A., Paredes, A., Loyola, L.A., Gallardo, O. and Borquez, J. 2003. Secondary metabolites from four medicinal plants from northern Chile: antimicrobial activity and biotoxicity against Artemia salina. J. Chil. Chem. Soc. 48, N2.

14. Kuddus, M.R., Rumi, F., Kaisar, M.A., Rahman, M.S., Hasan, C.M., Hassan, M.A. and Rashid, M.A. 2011. Secondary metabolites from Melocanna baccifera (Roxb.) Asian J. Chem. 23, 85-88. 